\title{
Monitorization of NGAL, Creatinine and Renal Blood Flow in the Follow-up of Acute Kidney Injury in Intensive Care
}

\section{Yoğun Bakımda Akut Böbrek Hasarı Takibinde NGAL, Kreatinin ve Renal Kan Akımının Monitörizasyonu}

\author{
Mehmet Süleyman Sabaz ${ }^{1 \oplus}$, Halil Çetingö ${ }^{2} \oplus$, Gokhan Sertcakacilar ${ }^{3} \oplus$, Yusuf Ziya Yener ${ }^{3 \oplus}$, Erdal Atiç ${ }^{3} \oplus$, \\ Aysun Erbahceci Salik ${ }^{4} \odot$, Evrim Kucur Tulubas ${ }^{3} \odot$, Gulsum Oya Hergunsel ${ }^{3} \odot$
}

${ }^{1}$ Department of Anesthesiology and Reanimation, Division of Intensive Care, Marmara University Pendik Training And Research Hospital, Istanbul, Turkey ${ }^{2}$ Department of Anesthesiology and Reanimation, Division of Algology, Istanbul University Istanbul Faculty Of Medicine, Istanbul, Turkey ${ }^{3}$ Department of Anesthesiology and Reanimation, Health Sciences University Bakırköy Dr Sadi Konuk Training And Research Hospital ${ }^{4}$ Department of radiology, Health Sciences University Bakırköy Dr Sadi Konuk Training And Research Hospital, Istanbul, Turkey

Received: 23.01.2021 / Accepted: 03.03.2021 / Published Online: 31.03.2021

Cite as: Sabaz MS, Çetingök H, Sertcakacilar G, Yener YZ, Atiç E, Erbahceci Salik A, Kucur Tulubas E, Hergunsel GO. Monitorization of NGAL, creatinine and renal blood flow in the follow-up of acute kidney injury in intensive care. Med J Bakirkoy 2021;17(1):85-93.

ABSTRACT

Objective: Acute Kidney Injury (AKI) and subsequent renal failure are the leading causes of morbidity and mortality in the intensive care unit (ICU). In this study, it was planned to compare Neutrophil Gelatinase-associated Lipocalin (NGAL) and creatinine values in patients diagnosed with AKI and to determine the effect of renal dose dopamine use on renal blood flow, development of chronic renal failure (CRF) and mortality. Methods: This prospective study was planned with 35 patients developed AKI in the ICU of Bakırköy Dr. Sadi Konuk Training and Research Hospital. The patients were randomized into 2 groups as 18 patients who received dopamine treatment with the recommendation of the cardiology clinic and 17 patients who did not receive dopamine treatment. Urea, creatinine and NGAL plasma levels were compared between groups.

Results: There was no difference between the groups in terms of age, gender and AKI stage. The 0th, 24th hour results and 24-hour changes of urea, creatinine and NGAL values of dopamine patient, who took dopamine, were found to be similar to those of patients who did not take dopamine. A significant positive correlation was found between the 24-hour change in creatinine value and the 24-hour change in NGAL $(r=0.374 ; p<0.05)$. There was no significant change in the diameter and flow of renal arteries between measurements in patients who received dopamine. The rates of patients who regain normal kidney functions, develop CRF or develop mortality between the two groups were found to be similar.

Conclusion: Treatment results of AKI developing in ICU are not satisfactory. Low-dose dopamine treatment has no effect on patient outcomes in these patients. NGAL is a biomarker that has the ability to show renal damage at an early stage. Serial measurement of NGAL concentration during ICU stay may benefit the clinician in early diagnosis and follow-up of AKI.

Keywords: Acute Kidney Injury, NGAL, Creatinine, Renal Doppler Ultrasonography, Intensive Care Unit

Öz

Amaç: Akut böbrek hasarı (AcuteKidneyInjury: AKI) ve sonrasında gelişen böbrek yetmezliği YBÜ’nde morbidite ve mortalite nedenlerinin başında yer alır. Bu çalışmada AKI tanııı alan hastalarda Nötrofil jelatinaz-iliş̧ili lipokalin (NGAL) ve kreatinin değerlerini karşılaştırmak, renal doz dopamin kullanımının, böbrek kan akımı, kronik böbrek yetmezliği (KBY) gelișimi ve mortalite üzerindeki etkisini belirlemek planlanmıștır. Yöntem: Bu prospektif araştırma Bakırköy Dr.Sadi Konuk Eğitim ve Araştırma Hastanesi YBÜ’nde, AKI gelişen toplam 35 hasta ile planlandı. Hastalar, kardiyoloji kliniğinin önerisi ile dopamin tedavisi alan 18 hasta ve dopamin tedavisi almayan 17 hasta olacak şekilde 2 gruba randomize edildi. Hastaların 0. ve 24. saatte üre, kreatinin ve NGAL plazma seviyeleri gruplar arasında karşılaştırıldı.

Bulgular: Gruplar arasında yas, cinsiyet ve AKI evresi açııından fark yoktu. Dopamin alan hastaların üre, kreatinin ve NGAL değerlerinin 0 . 24. saat sonuçları ve 24 saatlik değişimleri dopamin almayan hastalarla benzer bulundu. Kreatinin değerindeki 24 saatlik değişim ile NGAL değerindeki 24 saatlik değişim miktarı arasında anlamlı pozitif korelasyon olduğu belirlendi $(r=0.374 ; p<0,05)$. Dopamin alan hastalarda renal arterlerin çap ve akımında ölçümler arasında anlamlı değişiklik saptanmadı. iki grup arasında normal böbrek fonksiyonlarını geri kazanan, KBY gelişen veya mortalite gelişen hastaların oranları benzer bulundu.

Sonuç: Yoğun bakımda gelişen AKI'nin tedavi sonuçları tatmin edici değildir. Bu hastalarda düşük doz dopamin tedavisinin hasta sonuçlarına bir etkisi yoktur. NGAL, renal hasarı erken dönemde gösterme becerisine sahip bir biyobelirteçtir. YBÜ'nde kalış süresi boyunca NGAL konsantrasyonunun seri ölçümü AKI nin erken tanınması ve takibinde klinisyene fayda sağlayabilir.

Anahtar kelimeler: Akut Böbrek Hasarı, NGAL, Kreatinin, Renal Doppler Ultrasonografi, Yoğun Bakım Ünitesi

Corresponding Author: M.S. Sabaz 0000-0001-7034-0391

$\checkmark$ udmss_47@hotmail.com
H. Çetingök 0000-0002-6746-9079

G. Sertcakacilar 0000-0002-4574-0147
Y.Z. Yener 0000-0002-6368-5962

E. Atiç 0000-0003-1225-5871

A. Erbahceci Salik $0000-0001-5344-560 x$
E. Kucur Tulubas 0000-0001-9007-8685 G.O. Hergunsel 0000-0003-3218-0029

(c) Telif hakkı Sağlık Bilimleri Üniversitesi Bakırköy Dr. Sadi Konuk Eğitim ve Araştırma Hastanesi'ne aittir. Logos Tıp Yayıncılık tarafindan yayınlanmaktadır. Bu dergide yayınlanan bütün makaleler Creative Commons Atff-GayriTicari 4.0 Uluslararası Lisansı ile lisanslanmıştr.

(C) Copyright Health Sciences University Bakırköy Sadi Konuk Training and Research Hospital. This journal published by Logos Medical Publishing.

Licenced by Creative Commons Attribution-NonCommercial 4.0 International (CC BY) 


\section{INTRODUCTION}

Acute Kidney Injury (AKI) is a common clinical syndrome in hospitalized patients. AKI affects approximately $5 \%$ of hospitalized patients and $60 \%$ of patients admitted to the intensive care unit (ICU) ${ }^{(1-4)}$. Despite its prevalence and advances in supportive care, the mortality rate of patients developing AKI is above $50 \%{ }^{(1)}$. AKI Network (AKIN) prepared for AKI diagnosis or Kidney Disease: Guidelines such as Kidney Disease: Improving Global Outcomes (KDIGO) attempt to capture a sudden drop in glomerular filtration rate (GFR) associated with $\mathrm{AKI}$, by using data for an increase in serum creatinine and/or a decrease in urine output ${ }^{(5-7)}$. It is well understood that after a substantial reduction in GFR, serum creatinine levels rise ${ }^{(8)}$. However, the renal tubular epithelium, not the glomeruli, is the first site of injury in most types of AKI, and reduced GFR is a late and insensitive predictor ${ }^{(8)}$. Thus, relying solely on changes in serum creatinine can lead to a delay in AKI management and negative consequences. Apart from traditional biomarkers such as urea, creatinine, blood urea nitrogen (BUN), which are used to diagnose AKI, newly evaluated biomarkers are trying to establish a relationship with cellular damage that occurred long before the damage in GFR. In the last 10 years, great efforts have been made to find specific biomarkers that can detect acute damage to the renal tubular epithelium ${ }^{(8)}$. It has been shown that several new biomarkers such as neutrophil gelatinase-associated lipocalin (NGAL), cystatin C, and Kidney Injury Molecule-1 (KIM-1) are potentially successful in detecting the severity and etiology of AKI, and effective for the diagnosis of AKI in many clinical situations, such as bypass surgery, heart failure ${ }^{(9-12)}$. However, these biomarkers have been used mostly for research purposes.

The protein neutrophil gelatinase-associated lipocalin (NGAL) is made by neutrophils and other epithelial cells. It belongs to the lipocalin family of proteins, which transports small hydrophobic molecules including steroids, retinoids, and lipids ${ }^{(13-15)}$. Mishra et al. first suggested it in 2003 as a marker of early kidney damage due to renal hypoperfusion ${ }^{(15,16)}$. Renal tubular cells produce NGAL, a protein involved in natural immunity, in response to ischemic and toxic injury, and its concentration in serum and urine rises 8 to 24 hours before serum creatinine rises $(9,17)$.
In several different settings, NGAL has emerged as a promising noninvasive, responsive, and early AKI biomarker, and it is the most researched and cost-effective biomarker for $\operatorname{AKI}(9,18,19)$.

Dopamine is a catecholamine that affects the systemic and renal vasculature in a dose-dependent manner ${ }^{(20)}$. Dopamine acts on A1 receptors at low doses $(3 \mathrm{~g} / \mathrm{kg} / \mathrm{min})$, inducing vasodilation of the renal arteries and the mesenteric, coronary, and cerebral artery beds ${ }^{(20)}$. Low-dose dopamine has been suggested as a renal protective strategy in acute heart failure. Although some small studies in heart failure patients with reduced ejection fraction have shown improvement in urine output and renal blood flow, another low-dose study advocating the contrary found that dopamine use in the heart failure population with predominantly reduced ejection fraction did not have a positive effect on urine volume or cystatin $\mathrm{C}$ levels in the treatment of acute heart failure ${ }^{(20-23)}$. Dopamine is still an inotropic agent used in $25 \%$ of patients with acute heart failure and $14 \%$ of patients undergoing cardiac surgery, despite its diminishing use ${ }^{(24-26)}$.

In the light of this information, in this study, it is aimed to compare NGAL and creatinine values in the follow-up of patients diagnosed with AKI according to KDIGO guidelines, and to evaluate renal blood flow with Doppler Ultrasonography in patients who received dopamine treatment with the recommendation of the cardiology clinic and who did not receive dopamine, and to determine the relationship between dopamine use and renal function, mortality and morbidity.

\section{MATERIALS AND METHODS}

\section{Data center}

This research, which was planned in a prospective, randomized clinical study, was performed between March 2014 and December 2014 at Bakırköy Doktor Sadi Konuk Training and Research Hospital ICU in Istanbul, Turkey. Providing health services in 40 different medical branches, this hospital with a capacity of 652 beds and 27 patient beds accepts an average of 1640 medical, surgical or trauma patients requiring treatment, per year. In this center, where extracorporeal treatments (ECMO, hemodialysis, 
plasmapheresis) can be applied by Intensive Care specialists, Intensive Care minor assistants, Anesthesiology and Reanimation specialists and assistants 7 days 24 hours, which provides intensive care service as a closed unit, the patient-nurse ratio is $2: 1$.

\section{Data collection}

When a patient is comes to the ICU, the nurse measures his or her height and weight and records it in the clinical decision support system after the patient has removed his or her clothing and jewelry. Treatments such as intravenous fluid and diuretics provided prior to the patient's admission are not taken into account in this calculation. The patient's urine production is reported in the clinical decision support system on an hourly basis. In addition, the results of laboratory tests requested during the follow-up, such as creatinine and NGAL, are automatically uploaded to the system. With the AKI algorithm prepared according to the KDIGO criteria, by using these data the system monitors urine output and creatinine values hourly, and if AKI criteria are met, it creates a warning by determining its stage. It records this warning and gives an alarm to the user. In this way, the development of AKI is determined quickly and precisely.

The treatment of patients with $A K I$ is reviewed according to KDIGO criteria and nephrotoxic agents, if any, are excluded from the treatment. Dynamic measures are used to assess the patient's intravenous fluid needs, and adequate fluid therapy is arranged. Crystalloid solutions are used for liquid hydration and colloid agents are avoided. Hemodynamics of the patients are monitored in a way that the mean arterial blood pressure to be $65 \mathrm{~mm}$ hg and above. By keeping the partial oxygen pressure above $60 \mathrm{~mm} \mathrm{hg}$ and the partial carbon dioxide pressure below $50 \mathrm{~mm}$ hg, hypoxia and hypercarbia are avoided. The enteral route is preferred primarily in the nutrition of the patients, and the daily total energy is targeted as $20-30 \mathrm{kcal} / \mathrm{kg} /$ day.

\section{Study population}

Among 1364 patients, who were admitted to the ICU at the time of the study planning, it was planned that 18 patients, who were diagnosed with AKI and received dopamine treatment with the recommendation of the cardiology clinic for cardiac reasons and 17 patients, who were diagnosed with AKI but did not need dopamine, constitute the study sample. When AKI was diagnosed at the patients who were included in the study consecutively, blood was taken to determine urea, creatinine, NGAL plasma levels at $0^{\text {th }}$ and $24^{\text {th }}$ hours and the results were noted. In the first group of patients, who needed dopamine treatment, $2 \mathrm{mcg} / \mathrm{kg} / \mathrm{dk}$ dopamine infusion was started in addition to the classical treatment, and the other group was given the recommended classical treatment. Renal Doppler ultrasonography was performed in both groups at the time of diagnosis and 24 hours after the initiation of treatment by the same specialist radiologist with the same ultrasound device. Aortic exit of both renal arteries and hilus inlet diameter and flow were measured and noted. The relationship between urea, creatinine and NGAL plasma levels of the patients was evaluated. In addition, the results of renal Doppler ultrasonography were statistically compared in the patient groups that received conventional treatment and the other one, which received dopamine in addition to conventional therapy. The values offered in the study by Gordon et al. (1995) were used to determine the minimum sample size. In this previous study, it was determined that with the use of $2 \mathrm{mcg} /$ $\mathrm{kg} / \mathrm{min}$ dopamine, renal blood flow increased from $179 \mathrm{ml} / \mathrm{min}$ to $203 \mathrm{ml} / \mathrm{min}^{(27)}$. On the basis of the Type I error 0.05, Type II error 0.20 (80\% power), and with $1 / 1$ planned sampling structure, the $\mathrm{G}^{*}$ Power statistical program determined a minimum sample size of 16 patients.

\section{Inclusion criteria}

It was planned to include patients

Who were hospitalized in the ICU for more than 24 hours,

Between $18-80$ years,

Without chronic kidney failure, Who had not had a kidney transplant before.

\section{Exclusion Criteria}

Patients with chronic renal failure (CRF), Patients who need routine dialysis, Patients receiving dopamine at a dose higher than 2 $\mathrm{mcg} / \mathrm{kg} / \mathrm{min}$ dopamine dose

Patients who received an inotropic or vasopressor drug other than dopamine were excluded from the study. 


\section{Primary outcomes}

Research: was planned to compare NGAL and creatinine plasma levels in patients diagnosed with AKI according to KDIGO guidelines and to evaluate the effect of dopamine use on renal blood flow.

\section{Secondary outcomes}

It was aimed to evaluate the demographic data of the patients and to determine the effects of dopamine use on renal function, mortality, and morbidity by looking at classical markers such as urea and creatinine.

\section{Ethical issues}

Before starting the research, Institutional Permission and Ethics Committee approval was received from Bakırköy Dr. Sadi Konuk Training and Research Hospital Clinical Research Ethics Committee (Protocol code: 2014/46 -Decision no: 2014/04/11, Date: 03.03.2014) The study complies with the provisions of the 1995 Helsinki Declaration (as revised in Brazil in 2013).

\section{Statistical analysis}

The data collected in the study was evaluated with the SPSS 22.00 program. In the descriptive statistics of the data, mean, standard deviation, median, lowest, highest, frequency and ratio values were used. Chi-square test was used in the analysis of qualitative data, and Fisher's exact test was used when the conditions of the chi-square test were not met. The Kolmogorov Simirnov test was used to assess the distribution of variables. In the study of quantitative results, the independent sample t-test was used, and the Mann-Whitney $U$ test was used when the assumptions of this test could not be given.Paired sample $t$ test and Wilcoxon test were used in the analysis of repeated measures. Spearman correlation analysis was used for correlation analysis. For significance level, $p<0.05$ was accepted.

\section{RESULTS}

Patients included in the study were divided into two groups as patients who received dopamine treatment and those who did not receive. The demographic data of the patients are given in Table 1. The age, gender distribution, and AKI stage distribution of the patients were found to be similar between the groups ( $p>0.05$ ). Considering the comorbidities of the patients, the rate of Congestive Heart Failure (CHF) was found to be higher than the patients who received dopamine $(7$,

Table 1. Demographic characteristics, comorbidities and intensive care interventions of the patients

\begin{tabular}{|l|l|l|l|}
\hline \multicolumn{1}{|c|}{ Parameters } & \multicolumn{1}{|c|}{ Dopamine $+(\mathrm{n}: 17)$} & \multicolumn{1}{c|}{ Dopamine - (n:18) } & P value \\
\hline Age & $59.3 \pm 18.6$ & $47.5 \pm 23.8$ & 0.109 \\
\hline Gender & & & 0.088 \\
\hline Male & $10(55.6)$ & $14(82.4)$ & \\
\hline Female & $8(44.4)$ & $3(17.6)$ & \\
\hline AKI Stage & & & 0.369 \\
\hline Stage 1 & $15(83.3)$ & $12(70.6)$ & \\
\hline Stage 2 & $3(16.7)$ & $5(29.4)$ & \\
\hline Stage 3 & $0(0)$ & $0(0)$ & 0.214 \\
\hline Comorbidities & $12(70.6)$ & $9(50)$ & 0.625 \\
\hline DM & $8(47.1)$ & $7(38.9)$ & 0.241 \\
\hline HT & $9(52.9)$ & $6(33.3)$ & $0.192^{*}$ \\
\hline SVD & $6(35.3)$ & $3(16.7)$ & $0.620^{*}$ \\
\hline COPD & $4(23.5)$ & $4(22.2)$ & $0.049^{*}$ \\
\hline CHF & $7(41.2)$ & $2(11.1)$ & $0.642^{*}$ \\
\hline Malignity & $3(17.6)$ & $3(16.7)$ & $0.472^{*}$ \\
\hline Other & $3(17.6)$ & $2(11.1)$ & \\
\hline Interventions & & & 0.323 \\
\hline Arterial catheter & $16(94.1)$ & $4(22.2)$ & $0.117^{*}$ \\
\hline Central catheter & $8(47.1)$ & $12(66.7)$ & 0.129 \\
\hline Dialysis catheter & $15(88.2)$ & $11(61.1)$ & 0.328 \\
\hline Dialysis & $13(76.5)$ & $13(72.2)$ & 0.774 \\
\hline Mechanical ventilation & $13(76.5)$ & $608 D$ & \\
\hline
\end{tabular}

(AKI, Acute kidney injury; DM, Diabetes mellitus; HT, Hypertension; COPD, Chronic obstructive pulmonary disease; CHF, Chronic heart failure; SVD, Cerebrovascular disease)

${ }^{*}$ Fisher exact test 
$41.2 \%)$ compared to those who did not receive dopamine $(2,11.1 \%)$. Considering the interventions applied in the ICU, there was no difference between the groups in terms of arterial catheter, central catheter, dialysis, and mechanical ventilation applications $(p<0.05)$.

When the clinical parameters of the patients were examined, the 24-hour change in heart rate of the patients who received dopamine $(4 \pm 9)$ was found to be higher than the group that did not receive dopamine $(-2 \pm 11)$. While mean arterial pressure was higher in those who did not take dopamine $0^{\text {th }}$ hour $(94 \pm 14)$ than those who received dopamine (78 \pm 15$)$. No difference was found in $24^{\text {th }}$ hour and 24-hour change. Systolic blood pressure was higher in those who did not take dopamine at $0^{\text {th }}$ and $24^{\text {th }}$ hours. The 24-hour change did not differ significantly between groups. When the patients were evaluated in terms of biomarkers showing renal function, it was found that $0^{\text {th }}$ and $24^{\text {th }}$ hour results and $24^{\text {th }}$ hour changes of the urea, creatinine and NGAL values of the patients receiving dopamine were similar to the patients who did not receive dopamine (Table 2 ). The rates of patients who regain normal kidney functions, develop CRF or develop mortality between the two groups were found to be similar ( $p>0.05)$.

After the evaluation of the renal arteries with Doppler USG, the aortic outlet and hilus inlet diameter of the right renal artery were found to be higher in those who did not take dopamine, at $0^{\text {th }}$ hour. Aortic outlet diameter of the right renal artery remained high in patients who did not take dopamine, at $24^{\text {th }}$ hour $(p<0.05)$. There was no difference in the hilus inlet flow of the right renal artery, but the flow was higher at the aortic outlet at $0^{\text {th }}$ and $24^{\text {th }}$ hour in those who did not take dopamine. As a result of the evaluation of the left renal artery by USG, the diameter of the aortic outlet and hilus entrance were found to be higher in those who did not take dopamine, at $0^{\text {th }}$ and

Table 2. The clinical and laboratory parameters of the patients

\begin{tabular}{|c|c|c|c|}
\hline Parameters & Dopamine $+(\mathrm{n}: 17)$ & Dopamine - (n:18) & $\mathrm{P}$ value \\
\hline \multicolumn{4}{|l|}{ HR } \\
\hline $0 . \mathrm{hr}$ & $101 \pm 13$ & $101 \pm 15$ & 0.960 \\
\hline $24 . \mathrm{hr}$ & $104 \pm 12$ & $99 \pm 11$ & 0.188 \\
\hline Change within a period of 24 hours & $4 \pm 9$ & $-2 \pm 11$ & 0.032 \\
\hline \multicolumn{4}{|l|}{ Systolic arterial pressure } \\
\hline $0 . \mathrm{hr}$ & $116 \pm 21$ & $140 \pm 22$ & 0.003 \\
\hline 24.hr & $118 \pm 22$ & $132 \pm 18$ & 0.043 \\
\hline Change within a period of 24 hours & $0 \pm 16$ & $-8 \pm 27$ & 0.326 \\
\hline \multicolumn{4}{|l|}{ Mean arterial pressure } \\
\hline $0 . \mathrm{hr}$ & $78 \pm 15$ & $94 \pm 14$ & 0.004 \\
\hline $24 . \mathrm{hr}$ & $80 \pm 17$ & $89 \pm 16$ & 0.108 \\
\hline Change within a period of 24 hours & $1 \pm 13$ & $-4 \pm 19$ & 0.110 \\
\hline \multicolumn{4}{|l|}{ NGAL } \\
\hline $0 . \mathrm{hr}$ & $1012 \pm 576$ & $1397 \pm 2223$ & $0.741^{\star}$ \\
\hline 24.hr & $896 \pm 491$ & $1317 \pm 2360$ & $0.773^{*}$ \\
\hline Change within a period of 24 hours & $26 \pm 159$ & $-80 \pm 332$ & $0.692^{*}$ \\
\hline \multicolumn{4}{|l|}{ Creatinine } \\
\hline $0 . \mathrm{hr}$ & $1.9 \pm 0.6$ & $2.0 \pm 0.8$ & 0.947 \\
\hline $24 . \mathrm{hr}$ & $2.0 \pm 0.6$ & $1.8 \pm 0.8$ & 0.234 \\
\hline Change within a period of 24 hours & $0.03 \pm 0.54$ & $-0.23 \pm 0.49$ & 0.256 \\
\hline \multicolumn{4}{|l|}{ Urea } \\
\hline $0 . \mathrm{hr}$ & $102 \pm 61$ & $101 \pm 58$ & 0.974 \\
\hline 24.hr & $111 \pm 59$ & $96 \pm 54$ & 0.540 \\
\hline Change within a period of 24 hours & $10 \pm 18$ & $-5 \pm 27$ & 0.130 \\
\hline \multicolumn{4}{|l|}{ Kidney function } \\
\hline Mortality & $12(70.6)$ & $8(44.4)$ & 0.118 \\
\hline CKF & $1(5.6)$ & $3(17.6)$ & 0.323 \\
\hline Healthy kidney & $5(27.8)$ & $6(35.3)$ & 0.271 \\
\hline
\end{tabular}

(HR, Heart rate; hr, hour; CKF, chronic kidney failure)

${ }^{*}$ Independent sample $\mathrm{T}$ test 
Table 3. Renal artery diameter and flow values determined via Doppler ultrasonography

\begin{tabular}{|c|c|c|c|}
\hline Parameters & Dopamine $+(\mathrm{n}: 17)$ & Dopamine - (n:18) & P value \\
\hline \multicolumn{4}{|c|}{ Entrance diameter of right renal artery hilus } \\
\hline $0 . \mathrm{hr}$ & $3.7 \pm 0.7$ & $4.3 \pm 0.6$ & 0.017 \\
\hline 24.hr & $3.8 \pm 0.7$ & $4.0 \pm 0.8$ & 0.079 \\
\hline Change within a period of 24 hours & $-0.02 \pm 0.38$ & $0.02 \pm 0.65$ & 0.682 \\
\hline \multicolumn{4}{|c|}{ Stream of right renal artery hilus entrance } \\
\hline $0 . \mathrm{hr}$ & $37.5 \pm 10.7$ & $41.9 \pm 10.6$ & 0.133 \\
\hline 24.hr & $37.9 \pm 10.0$ & $40.4 \pm 9.3$ & 0.330 \\
\hline Change within a period of 24 hours & $-0.4 \pm 6.4$ & $-1.5 \pm 9.8$ & 0.638 \\
\hline \multicolumn{4}{|c|}{ Diameter of right renal arterial aortic outflow } \\
\hline $0 . \mathrm{hr}$ & $3.9 \pm 0.8$ & $4.6 \pm 0.6$ & 0.005 \\
\hline 24.hr & $4.0 \pm 0.8$ & $4.6 \pm 0.7$ & 0.016 \\
\hline Change within a period of 24 hours & $0.0 \pm 0.5$ & $-0.0 \pm 0.6$ & 0.335 \\
\hline \multicolumn{4}{|c|}{ Stream of right renal arterial aortic outflow } \\
\hline $0 . \mathrm{hr}$ & $39.1 \pm 10.6$ & $46.2 \pm 14.2$ & 0.023 \\
\hline 24.hr & $40.9 \pm 10.8$ & $45.8 \pm 10.7$ & 0.176 \\
\hline Change within a period of 24 hours & $1.3 \pm 6.4$ & $-0.4 \pm 13.6$ & 0.192 \\
\hline \multicolumn{4}{|c|}{ Entrance diameter of left renal artery hilus } \\
\hline $0 . \mathrm{hr}$ & $3.7 \pm 0.7$ & $4.3 \pm 0.6$ & 0.011 \\
\hline 24.hr & $3.8 \pm 0.7$ & $4.4 \pm 0.7$ & 0.011 \\
\hline Change within a period of 24 hours & $0.1 \pm 0.4$ & $0.1 \pm 0.9$ & 0.210 \\
\hline \multicolumn{4}{|l|}{ Stream of left renal artery hilus entrance } \\
\hline $0 . \mathrm{hr}$ & $37.6 \pm 11.2$ & $42.9 \pm 10.6$ & 0.077 \\
\hline 24.hr & $38.5 \pm 11.7$ & $40.8 \pm 10.7$ & 0.493 \\
\hline Change within a period of 24 hours & $0.3 \pm 5.4$ & $-2.1 \pm 9.3$ & 0.199 \\
\hline \multicolumn{4}{|c|}{ Diameter of left renal artery aortic outflow } \\
\hline $0 . \mathrm{hr}$ & $3.9 \pm 0.8$ & $4.6 \pm 0.5$ & 0.002 \\
\hline 24.hr & $3.9 \pm 0.8$ & $4.6 \pm 0.6$ & 0.006 \\
\hline Change within a period of 24 hours & $0.0 \pm 0.4$ & $-0.1 \pm 0.5$ & 0.537 \\
\hline \multicolumn{4}{|c|}{ Stream of left renal arterial aortic outflow } \\
\hline $0 . \mathrm{hr}$ & $40.3 \pm 11.8$ & $48.6 \pm 9.1$ & 0.018 \\
\hline 24.hr & $40.8 \pm 12.3$ & $46.0 \pm 11.1$ & 0.171 \\
\hline Change within a period of 24 hours & $-0.2 \pm 6.8$ & $-2.6 \pm 9.8$ & 0.194 \\
\hline
\end{tabular}

(hr, hour)

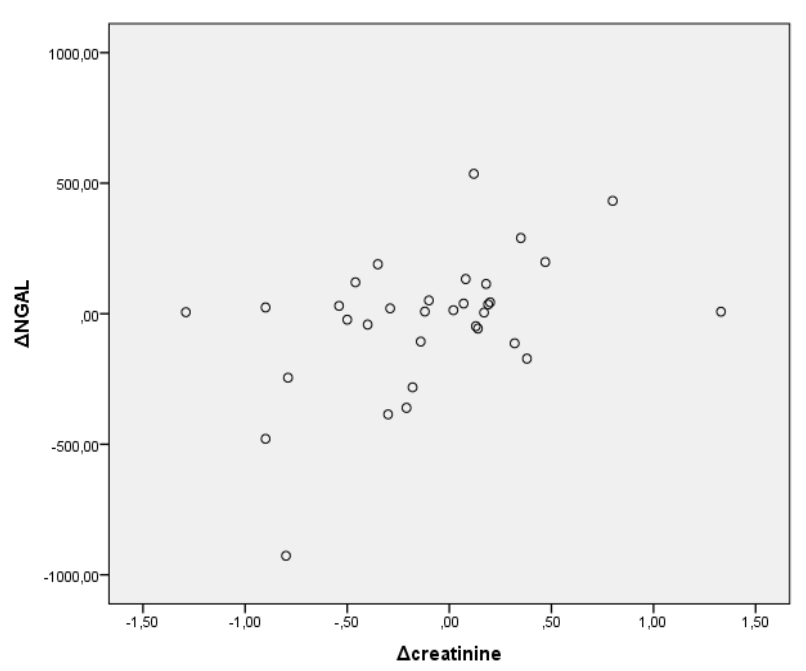

Figure 1. 24-hour change graph of NGAL and creatinine plasma levels $24^{\text {th }}$ hours. It was found that the aortic outlet flow of the left renal artery was higher in those who did not take dopamine, at $0^{\text {th }}$ hour $(p<0.05)$. The hilus inflow flows of the left renal artery were found to be similar in the two groups (Table 3).

As a result of the correlation analysis of the biomarkers used for the diagnosis of AKI, no significant correlation was found between the 0 -hour and 24-hour creatinine value and the $0^{\text {th }}$ hour and $24^{\text {th }}$ hour NGAL values ( $p>0.05$ ). However, as a result of the correlation analysis of the 24-hour change, it was determined that there was a significant positive correlation ( $r=0.374 ; p<0.05$ ) between the 24-hour change in creatinine value and the 24-hour change in NGAL (Figure 1). 


\section{DISCUSSION}

In this study, it was found that there was a correlation between 24-hour change in creatinine plasma level and 24-hour change in NGAL plasma level in the follow-up of patients diagnosed with AKI according to KDIGO criteria. This finding indicates that NGAL can be used not only in the diagnosis of AKI but also in its follow-up. Previous studies have determined that there is a correlation between NGAL and creatinine levels, consistent with our results ${ }^{(28-30)}$. AKI can cause serious consequences such as renal failure, end-stage renal failure requiring long-term renal replacement therapy (RRT), and even death. Studies show that AKI is an independent predictor of mortality ${ }^{(31)}$. There is no satisfactory treatment for AKI ${ }^{(32-34)}$. Therefore, there is a consensus that the prevention of AKI among those at risk and that it should be paid attention to its early diagnosis before irreversible tissue damage occurs ${ }^{(35-37)}$. The distinct advantage of biomarkers such as NGAL is that plasma levels increase in the earlier period of kidney damage, before increases in serum creatinine or BUN. In a meta-analysis study, NGAL plasma levels were found to be a biomarker with high diagnostic value for AKI, in addition, it was determined to be a potential predictor for RRT and mortality need ${ }^{\left({ }^{37}\right)}$. Another meta-analysis found that NGAL has acceptable validity in detecting acute kidney injury in patients with normal pre-operative renal function following cardiac surgery ${ }^{(38,39)}$. Our findings were in line with both of these meta-analyses, suggesting that plasma NGAL value can be used as a biomarker to predict the progression of kidney damage and the need for RRT ${ }^{(39)}$.

Increased NGAL levels after admission to the intensive care unit have a prognostic significance. A review conducted in 2014 found that 8,500 critically ill patients were included in the adaptations associated with NGAL and showed excellent predictive performance ${ }^{(40)}$. In a study comparing 5 biomarkers in 2635 patients, NGAL was found to be the most effective biomarker with $81 \%$ specificity and $68 \%$ sensitivity ${ }^{(41)}$. Therefore, in order to monitor deterioration in renal function, serial measurement of NGAL concentration during ICU stay, instead of a single point control of this biomarker on hospitalization may be beneficial to the clinician in early diagnosis and follow-up of AKI. In the critical care environment, an early rise in plasma
NGAL level will trigger emergency response. Leastwise, clinicians aware of such a situation will avoid the use of additional nephrotoxins and consider hydration and renal perfusion optimization to prevent further damage.

In recent years, the importance of low-dose dopamine in intensive care medicine has declined due to its ineffectiveness in preventing or ameliorating renal failure in critically ill patients. The use of this agent is based on the assumption that dopamine improves renal blood flow, which is a desirable outcome ${ }^{(42,43)}$. However, contrary to this situation, no increase in flow or diameter in renal arteries due to dopamine use was found in our study. In a similar study, unlike our research results, Blood flow in the renal interlobar arteries was analyzed before and after the administration of dopamine at a dose of $2 \mathrm{mcg} / \mathrm{kg} / \mathrm{min}$ by Doppler USG to critically ill patients followed in the ICU, Increased blood flow was observed with renal vasodilation after dopamine administration and this was confirmed by invasive tests ${ }^{\left({ }^{44}\right)}$. The difference of our study from this study is that all patients are followed up with a diagnosis of AKI. Indeed, in another prospective double-blind randomized controlled study conducted by Lauschke et al. low-dose dopamine was compared with Doppler USG in patients diagnosed with acute kidney injury and in patients with normal renal function. It was observed that dopamine reduced renal vascular resistance in the control group, and that it worsened renal perfusion rather than improving it in patients with AKI ${ }^{(33)}$. In another study, although dopamine increased external medullary blood flow in hypovolemic animals, it failed to improve external medullary dysoxia ${ }^{(45)}$. The natriuretic effects of dopamine through inhibition of proximal tubular resorption result in increased solution delivery to distal tubular cells. This can increase medullary oxygen intake, increasing rather than decreasing the risk of ischemia $(43,46)$. This aspect of kidney physiology may explain why drugs that improve renal blood flow aren't helpful. According to this example, certain agents will be dangerous. Studies have suggested that despite the increase in renal blood flow, dopamine worsens radiocontrast agents and secondary renal tubular damage in patients after cardiac surgery $(43,47,48)$. Finally, medications that suppress dopamine production, such as metoclopramide or haloperidol, are not linked to $\mathrm{AKI}$, despite their widespread usage 
in the same populations as low-dose dopamine, and despite the fact that these agents effectively eliminate low-dose dopamine's renal vascular impact $(43,49$, ${ }^{50)}$. However, a notable finding of our analysis is that dopamine does not increase the risk of death, CRF, or haemodialysis. In fact, dopamine appears to be a relatively safe agent, although completely ineffective for preventing or treating kidney dysfunction ${ }^{(43)}$.

The prospective design of our study has some limitations as well as its strengths such as consisting of randomized patients and a control group. The study is designed in a single center and has a relatively small patient population that prevents any subgroup analysis. NGAL plasma level is only detected when AKI diagnosis was made and at $24^{\text {th }}$ hour. In addition, patients with KDIGO stage I and II were included in the study, and patients who had a diagnosis of KDIGO stage III AKI but did not yet progress to require RRT could not be evaluated.

\section{CONCLUSION}

AKI emerges as an important cause of mortality and morbidity in intensive care. AKI does not yet have a satisfactory treatment, and the use of low-dose dopamine therapy in AKI patients has no clinical benefit. Therefore, early detection of renal damage is an especially important factor in early diagnosis and success of treatment. NGAL is an important biomarker that has the ability to show renal damage at an early stage. Serial measurement of NGAL concentration during ICU stay may be beneficial to the clinician in the early diagnosis and follow-up of AKI.

Ethics Committee Approval: Bakirkoy Dr. Sadi Konuk Training and Research Hospital (03.03.2021 /2014/04).

Conflict of Interest: The authors declare they have no conflict of interest.

Funding: The authors declared that this study received no financial support.

Informed Consent: Participants were informed about the study, and written consent was obtained from them. For the patients who were unable to give their consent was obtained from their guardians.

\section{REFERENCES}

1. Brivet FG, Kleinknecht DJ, Loirat P, Landais PJ. Acute renal failure in intensive care units-causes, outcome, and prognostic factors of hospital mortality; a prospective, multicenter study. French study group on acute renal failure. Crit Care Med. 1996;24:192-8. doi: 10.1097/00003246-199602000-00003.

2. Hou SH, Bushinsky DA, Wish JB, Cohen JJ, Harrington JT. Hospitalacquired renal insufficiency: a prospective study. Am J Med. 1983;74: 243-8. doi: 10.1016/0002-9343(83)90618-6.

3. Hoste EA, Bagshaw SM, Bellomo R, et al. Epidemiology of acute kidney injury in critically ill patients: the multinational AKI-EPI study. Intensive Care Med. 2015;41(8):1411-23. doi: 10.1007/s00134-015-3934-7.

4. National Confidential Enquiry into Patient Outcome and Death. Adding insult to injury: a review of the care of patients who died in hospital with a primary diagnosis of acute kidney injury (acute renal failure). Available from: https://www.ncepod.org. uk/2009report1/Downloads/AKI_report.pdf

5. Kidney Disease: Improving Global Outcomes (KDIGO) CKD-MBD Work Group. KDIGO clinical practice guideline for the diagnosis, evaluation, prevention, and treatment of Chronic Kidney Disease-Mineral and Bone Disorder (CKD-MBD). Kidney Int Suppl. 2009;(113):S1-130. doi: $10.1038 / \mathrm{ki} .2009 .188$

6. Mehta RL, Kellum JA, Shah SV, et al. Acute Kidney Injury Network: report of an initiative to improve outcomes in acute kidney injury. Crit Care. 2007;11(2):R31. doi: $10.1186 /$ cc5713.

7. Moledina DG, Parikh CR. Phenotyping of acute kidney injury: beyond serum creatinine. Semin Nephrol. 2018;38(1):3-11. doi: 10.1016/j.semnephrol.2017.09.002.

8. Srisawat N, Kellum JA. The role of biomarkers in acute kidney injury. Crit Care Clin. 2020;36(1):125-40. doi: 10.1016/j.ccc.2019.08.010.

9. Antonelli A, Allinovi M, Cocci A, et al. The predictive role of biomarkers for the detection of acute kidney injury after partial or radical nephrectomy: a systematic review of the literature. Eur Urol Focus. 2020;6(2):344-53. doi: 10.1016/j.euf.2018.09.020.

10. Andreucci M, Faga T, Pisani A, Perticone M, Michael A. The ischemic/nephrotoxic acute kidney injury and the use of renal biomarkers in clinical practice. Eur J Intern Med. 2017;39:1-8. doi: 10.1016/j.ejim.2016.12.001.

11. Sirota JC, Walcher A, Faubel S, et al. Urine IL-18, NGAL, IL-8 and serum IL-8 are biomarkers of acute kidney injury following liver transplantation. BMC Nephrol. 2013;14:17. doi: 10.1186/1471-2369-14-17.

12. Mishra J, Dent C, Tarabishi R, et al. Neutrophil gelatinase-associated lipocalin (NGAL) as a biomarker for acute renal injury after cardiac surgery. Lancet. 2005;365:1231-8. doi: 10.1016/S0140-6736(05)74811-X.

13. Devarajan P. Neutrophil gelatinase-associated lipocalin - an emerging troponin for kidney injury. Nephrol Dial Transplant. 2008;23:3737-43. doi: $10.1093 /$ ndt/gfn531.

14. Flower DR, Attwood TK, North AC. Structure and sequence relationships in the lipocalins and related proteins. Protein Sci. 1993;2:753-61. doi: $10.1002 /$ pro.5560020507.

15. Algethamy HM, Albeladi FI. Urinary neutrophil gelatinase-associated lipocalin is an excellent predictor of mortality in intensive care unit patients. Saudi Med J. 2017 Jul;38(7):706-714.

16. Mishra J, Ma Q, Prada A, et al. Identification of neutrophil gelatinase-associated lipocalin as a novel early urinary biomarker for ischemic renal injury. J Am Soc Nephrol. 2003;14:2534-43. doi: 10.1097/01.ASN.0000088027.54400.C6.

17. Mårtensson J, Bellomo R. The rise and fall of NGAL in acute kidney injury. Blood Purif. 2014;37(4):304-10. doi: $10.1159 / 000364937$ 
18. Ronco C, Legrand M, Goldstein SL, et al. Neutrophil gelatinaseassociated lipocalin: ready for routine clinical use? An international perspective. Blood Purif. 2014;37(4):271-85. doi: 10.1159/000360689.

19. Zafar Mohtashami A, Hadian B, Mahmoudi GA, Anbari K, Salahbarzin A. The application of urinary NGAL Measurement for early detection of $\mathrm{AKI}$ in hospitalized patients with poisoning. Iran J Kidney Dis. 2020;14(3):206-11. Available from: http://eprints. lums.ac.ir/2079/1/4966-24363-1-PB.pdf

20. Sharma K, Vaishnav J, Kalathiya R, Hu JR, Miller J, Shah N, Hill T, Sharp M, Tsao A, Alexander KM, Gupta R, Montemayor K, Kovel L, Chasler JE, Lee YJ, Fine DM, Kass DA, Weiss RG, Thiemann DR, Ndumele CE, Schulman SP, Russell SD; Osler Medical Housestaff. Randomized Evaluation of Heart Failure With Preserved Ejection Fraction Patients With Acute Heart Failure and Dopamine: The ROPA-DOP Trial. JACC Heart Fail. 2018 Oct;6(10):859-870.

21. Friedrich JO, Adhikari N, Herridge MS, Beyene J. Meta-analysis: low-dose dopamine increases urine output but does not prevent renal dysfunction or death. Ann Intern Med. 2005;142:510-24. doi: 10.7326/0003-4819-142-7-200504050-00010.

22. Elkayam U, Ng TM, Hatamizadeh P, Janmohamed M, Mehra A. Renal vasodilatory action of dopamine in patients with heart failure: magnitude of effect and site of action. Circulation. 2008;117:200-5. doi: 10.1161/CIRCULATIONAHA.107.737106.

23. Chen $\mathrm{HH}$, Anstrom KJ, Givertz MM, et al. Lowdose dopamine or low-dose nesiritide in acute heart failure with renal dysfunction: the ROSE acute heart failure randomized trial. JAMA. 2013;310:2533-43 doi: 10.1001/jama.2013.282190.

24. Thongprayoon C, Cheungpasitporn W, Harrison AM, et al. Temporal trends in the utilization of vasopressors in intensive care units: an epidemiologic study. BMC Pharmacol Toxicol. 2016;17(1):19. doi: 10.1186/s40360-016-0063-z.

25. Mebazaa A, Motiejunaite J, Gayat E, et al. Long-term safety of intravenous cardiovascular agents in acute heart failure: results from the European Society of Cardiology Heart Failure LongTerm Registry. Eur J Heart Fail. 2018;20:332-41. doi: 10.1002/ejhf.991.

26. Hiemstra B, Koster G, Wetterslev J, Gluud C, Jakobsen JC, Scheeren TWL, Keus F, van der Horst ICC. Dopamine in critically ill patients with cardiac dysfunction: A systematic review with meta-analysis and trial sequential analysis. Acta Anaesthesiol Scand. 2019 Apr;63(4):424-437.

27. Gordon IL, Wesley R, Wong DH, Ingegno MD, Spivak B, Wilson SE. Effect of dopamine on renal blood flow and cardiac output. Arch Surg. 1995;130(8):864-8 doi: 10.1001/archsurg.1995.01430080066010.

28. Gul A, Yilmaz R, Ozmen ZC, Gumuser R, Demir O, Unsal V. Assessment of renal function in obese and overweight children with NGAL and KIM-1 biomarkers. Nutr Hosp. 2020;34(3):436-42. doi: 10.20960/nh.02651.

29. Basturk T, Sari O, Koc Y, et al. Prognostic significance of NGAL in early stage chronic kidney disease. Minerva Urol Nefrol. 2017;69(3):307-12 doi: 10.23736/S0393-2249.16.02770-3.

30. Zhang J, Han J, Liu J, Liang B, Wang X, Wang C. Clinical significance of novel biomarker NGAL in early diagnosis of acute renal injury. Exp Ther Med. 2017;14(5):5017-21. doi: $10.3892 /$ etm.2017.5150.

31. Umbro I, Gentile G, Tinti F, Muiesan P, Mitterhofer AP. Recent advances in pathophysiology and biomarkers of sepsis-induced acute kidney injury. J Infect. 2016;72:131-42 doi: 10.1016/j.jinf.2015.11.008.

32. Bellomo R, Chapman M, Finfer S, Hickling K, Myburgh J. Lowdose dopamine in patients with early renal dysfunction: a placebo-controlled randomised trial. Australian and New Zealand Intensive Care Society (ANZICS) Clinical Trials Group. Lancet. 2000;356(9248):2139-43. doi: 10.1016/s0140-6736(00)03495-4

33. Lauschke A, Teichgraber UK, Frei U, Eckardt KU. "Low-dose" dopamine worsens renal perfusion in patients with acute renal failure. Kidney Int. 2006;69:1669-74.

doi: $10.1038 /$ sj.ki.5000310.

34. Allgren RL, Marbury TC, Rahman SN, et al. Anaritide in acute tubular necrosis. Auriculin Anaritide Acute Renal Failure Study Group. N Engl J Med. 1997;336:828-34. doi: 10.1056/NEJM199703203361203.

35. Kellum JA, Mehta RL, Levin A, et al. Development of a clinical research agenda for acute kidney injury using an international, interdisciplinary, three-step modified Delphi process. Clin J Am Soc Nephrol. 2008;3:887-94. doi: 10.2215/CJN.04891107.

36. Kellum JA, Levin N, Bouman C, Lameire N. Developing a consensus classification system for acute renal failure. Curr Opin Crit Care. 2002;8:509-14 doi: 10.1097/00075198-200212000-00005

37. Haase M, Bellomo R, Devarajan P, Schlattmann P, Haase-Fielitz A Accuracy of neutrophil gelatinase-associated lipocalin (NGAL) in diagnosis and prognosis in acute kidney injury: a systematic review and meta-analysis. Am J Kidney Dis. 2009;54:1012-24. doi: 10.1053/j.ajkd.2009.07.020.

38. Zhou F, Luo Q, Wang L, Han L. Diagnostic value of neutrophil gelatinase-associated lipocalin for early diagnosis of cardiac surgery-associated acute kidney injury: a meta-analysis. Eur J Cardiothorac Surg. 2016;49(3):746-55. doi: $10.1093 /$ ejcts/ezv199.

39. Mahmoodpoor A, Hamishehkar H, Fattahi V, Sanaie S, Arora P, Nader ND. Urinary versus plasma neutrophil gelatinase-associated lipocalin (NGAL) as a predictor of mortality for acute kidney injury in intensive care unit patients. J Clin Anesth. 2018 Feb;44:12-17.

40. Haase-Fielitz A, Haase M, Devarajan P. Neutrophil gelatinase-associated lipocalin as a biomarker of acute kidney injury: a critical evaluation of current status. Ann Clin Biochem. 2014;51(Pt 3):335-51. doi: 10.1177/0004563214521795.

41. Nickolas TL, Schmidt-Ott KM, Canetta P, et al. Diagnostic and prognostic stratification in the emergency department using urinary biomarkers of nephron damage: a multicenter prospective cohort study. J Am Coll Cardiol. 2012;59(3):246-55. doi: 10.1016/j.jacc.2011.10.854.

42. Carcoana OV, Hines RL. Is renal dose dopamine protective or therapeutic? Yes. Crit Care Clin. 1996;12(3):677-85 doi: 10.1016/S0749-0704(05)70271-2.

43. Kellum JA, M Decker J. Use of dopamine in acute renal failure: a meta-analysis. Crit Care Med. 2001 Aug;29(8):1526-31.

44. Stevens PE, Bolsin S, Gwyther SJ, Hanson ME, Boultbee JE, Kox W. Practical use of duplex Doppler analysis of the renal vasculature in critically ill patients. Lancet. 1989;1(8632):240-2. doi: 10.1016/S0140-6736(89)91257-9.

45. Heyman SN, Kaminski N, Brezis M. Dopamine increases renal medullary blood flow without improving regional hypoxia. Exp Nephrol. 1995;3(6):331-7. PMID: 8528677.

46. Olsen NV, Hansen JM, Ladefoged SD, Fogh-Andersen N, Leyssac PP. Renal tubular reabsorption of sodium and water during infusion of low-dose dopamine in normal man. Clin Sci (Lond). 1990;78(5):503-7. doi: $10.1042 / \operatorname{cs} 0780503$.

47. Weisberg LS, Kurnik PB, Kurnik BR. Risk of radiocontrast nephropathy in patients with and without diabetes mellitus. Kidney Int 1994;45(1):259-65. doi: 10.1038/ki.1994.32.

48. Tang AT, El-Gamel A, Keevil B, et al. The effect of 'renal-dose' dopamine on renal tubular function following cardiac surgery: Assessed by measuring retinol binding protein (RBP). Eur J Cardiothorac Surg. 1999;15:717-22. doi: 10.1016/S1010-7940(99)00081-0.

49. Manara AR, Bolsin S, Monk CR, Hartnell G, Harris RA. Metoclopramide and renal vascular resistance. $\mathrm{Br} J$ Anaesth. 1991;66(1):129-30. doi: 10.1093/bja/66.1.129.

50. Felder RA, Blecher M, Calcagno PL, et al. Dopamine receptors in the proximal tubule of the rabbit. Am J Physiol. 1984;257:F499-505. doi: 10.1152/ajprenal.1984.247.3.F499. 